\title{
Manuais de ensino de História oitocentistas: reflexões sobre o cristianismo na história escolar no Império do Brasil
}

Eighteenth-century History teaching manuals: reflections on Christianity in school history in the Brazilian Empire

Manuales de enseñanza de Historia oitocentistas: reflexiones sobre el cristianismo en la historia escolar en el Imperio de Brasil

José Petrúcio de Farias Júnior

Universidade Federal do Piauí (Brasil)

http://lattes.cnpq.br/2921343413261339

https://orcid.org/0000-0002-7631-0705

petruciojr@terra.com.br

Selva Guimarães

Universidade de Uberaba (Brasil)

Bolsista de Produtividade em Pesquisa do CNPq

http://lattes.cnpq.br/6146634282412140

https://orcid.org/0000-0002-8956-9564

selva.guimaraes@uniube.br

\section{Resumo}

Este texto apresenta resultados de uma investigação acerca dos compêndios de História Universal, de Victor Duruy e Pedro Parley, aprovados e adotados pelo Estado Imperial brasileiro para o ensino da História nas escolas secundárias de 1854 a 1878. Neste período, aconteceram as Reformas Educacionais de Couto Ferraz (1854) e de Leôncio de Carvalho de 1878. Analisa-se, então, no contexto dessas Reformas, o papel dos Manuais didáticos, na disseminação do Cristianismo, do ideal de Nação e de cidadania, a partir da histórica escolar. Para impor ideias e preceitos politicas e culturais o Estado Imperial aprovou o Regulamento da Instrução Primária e Secundária, cuja responsabilidade era fiscalizar e orientar o ensino público e particular nos níveis primário e secundário, estabelecendo normas para o exercício da liberdade de ensino.

Palavras-chave: Livro Didático. Cristianismo na escola. Ensino de História Antiga. 


\begin{abstract}
This text presents the results of an investigation about the compendia of Universal History by Victor Duruy and Pedro Parley, approved and adopted by the Brazilian Imperial State for the teaching of History in secondary schools from 1854 to 1878. During this period, there were the Educational Reforms of Couto Ferraz (1854) and Leôncio de Carvalho (1878). Then, in the context of these Reforms, it is analyzed the role of the Didactic Manuals, in the dissemination of Christianity, the ideal of Nation and of citizenship from the school history. In order to impose political and cultural ideas and precepts, the Imperial State approved the Regulation of Primary and Secondary Education, which was responsible for overseeing and guiding public and private education at the primary and secondary levels, establishing norms for the exercise of freedom of education.
\end{abstract}

Keywords: Textbook. Christianity in school. Teaching of Ancient History.

\title{
Resumen
}

Este artículo presenta resultados de una investigación acerca de los compendios de Historia Universal, de Victor Duruy y Pedro Parley, aprobados y adoptados por el Estado Imperial brasileño para la enseñanza de la Historia en las escuelas secundarias de 1854 a 1878. En este período, se realizaron las Reformas Educativas de Couto Ferraz (1854) y de Leôncio de Carvalho de 1878. Se analiza, entonces, en el contexto de esas Reformas, el papel de los manuales didácticos, en la diseminación del cristianismo, del ideal de nación y de ciudadanía, a partir de la histórica escolar. Para imponer ideas y preceptos políticos y culturales el Estado Imperial aprobó el Reglamento de la Instrucción Primaria y Secundaria, cuya responsabilidad era fiscalizar y orientar la enseñanza pública y privada en los niveles primario y secundario, estableciendo normas para el ejercicio de la libertad de enseñanza.

Palabras clave: Libro Didáctico. Cristianismo en la escuela. Enseñanza de Historia Antigua. 


\section{Introdução}

O uso dos compêndios de História Universal - de Victor Duruy (1865) e Pedro Parley (1869) - nas escolas secundárias trouxe uma série de implicações político-culturais no período imperial brasileiro, especificamente no ensino da História do Cristianismo no Império Romano. Aprovados e adotados pelo Estado Imperial, os manuais escolares, após a reforma educacional Couto Ferraz (1854), foram marcados não apenas pelas circunstâncias históricas, mas também com as chancelas de autoria e destinário.

O período recortado para este estudo é de 1854 a 1878 e compreende, respectivamente, o processo de implementação do primeiro Programa de Ensino - aprovado pelo Conselho Diretor, órgão criado pelo regulamento de 17 de fevereiro de 1854, decorrente da Reforma Educacional de Couto Ferraz (1854) -, e a reforma educacional de Leôncio de Carvalho de 1878. Nesse período, os projetos educacionais dos grupos conservadores católicos perdem espaço para grupos liberais que passam a disseminar propostas positivistas, marcadas pelas ideias de progresso e evolução (CARVALHO, 2003). A partir da reforma educacional de 1878, o ensino religioso tornou-se facultativo e os chamados "acatólicos" tiveram liberdade de ensinar, desvinculando os conteúdos curriculares à teologia católica.

Problematizaremos, em particular, os usos e as formas históricas que compreendem o processo de aceitação do Cristianismo Niceno (o nome está relacionado com o Primeiro Concílio de Niceia, em 325) no Império Romano, sob a administração do imperador Constantino (306$337)^{1}$ e sua oficialização sob Teodósio (379-395). Tendo em vista a natureza do objeto de investigação, a metodologia utilizada foi a pesquisa bibliográfica e documental, tendo como referencial Cellard (2012, p. 295), para quem o documento escrito "uma fonte extremamente preciosa para todo pesquisador nas ciências sociais", uma vez que "permite acrescentar a dimensão do tempo à compreensão do social". A partir desse entendimento sobre a análise documental, podemos inferir que o Cristianismo foi objeto de utilizações justificadoras e legitimadoras de projetos de nação que forjaram, a partir de 1850, as narrativas escolares dos manuais de história, impregnando-as, a nosso ver, de questões políticas dos Estados.

A Reforma de Couto Ferraz foi tomada como referência para as reflexões por três motivos: primeiro por se tratar de um esforço governamental pela uniformização do ensino secundário em escala nacional, a partir da organização curricular implantada no Imperial Colégio Pedro II -ICPII, ou seja, o currículo de tal unidade escolar passou a ser, em tese, uma espécie de núcleo irradiador de propostas curriculares às escolas secundárias provinciais; segundo, pelo controle e vigilância sobre instituições escolares, professores e produções didáticas, estabelecidos por meio da criação de órgãos e cargos públicos com tais atribuições; terceiro, por promover o ensino religioso, segundo a moral cristã, tanto no nível elementar quanto secundário, o que estabelece uma relação direta com a história escolar, nosso objeto de investigação.

Diante do processo de centralização política do Império do Brasil no Segundo Reinado e à formulação de um programa de ensino para a instrução pública secundária que, a partir do Colégio Pedro II, se estende às demais instituições de ensino do País, buscamos compreender como a narrativa histórica escolar dos Manuais está interligada à construção de uma identidade nacional que se vincula aos interesses e objetivos políticos de grupos que ocupavam os espaços de poder. Propomos, dessa maneira, uma vertente interpretativa que concebe a escrita da história escolar como um dos caminhos para compreender a relação mútua entre o Estado e religião; componentes, a nosso ver, indispensáveis para forjar uma identidade nacional no momento histórico em questão.

\footnotetext{
${ }^{1}$ Flávio Valério Constantino governou Roma entre 306 e 337 e ficou reconhecido, pela historiografia, como o primeiro imperador pró-cristão.
} 
Na primeira parte, focalizamos o processo de estabelecimento e gestão da instrução secundária brasileira, no âmbito da Reforma de Couto Ferraz (1854), enfatizando a legislação educacional, responsável pela definição da organização curricular, pela contratação e fiscalização dos docentes, bem como pela produção e regulação das edições escolares, porquanto entendemos que a história escolar não está dissociada da emergência de projetos políticos endereçados à instrução pública.

Tal discussão é indispensável para refletirmos sobre a produção, distribuição e utilização dos compêndios de História Universal, bem como esboçar o perfil dos autores/produtores dos manuais investigados. Analisamos como a versão da história do cristianismo difundida nos manuais didáticos oitocentistas, principalmente nos manuais de ensino de Victor Duruy, vincula-se aos interesses e objetivos da política imperial.

Trata-se de uma reflexão sobre as concepções de história que subsidiaram a narrativa histórica escolar; a emergência do discurso cristão pelo poder imperial e a oficialização do Cristianismo, no final do IV século. Assim,

[...] hoje se tem procurado perceber na historiografia sobre o Mundo Antigo que imagens e lógicas históricas, em maior ou menor grau, estão comprometidas com o contemporâneo, o que consiste em pensar não apenas a História, mas suas próprias tradições interpretativas [...]. (SILVA, 2011, p. 10)

Segundo esse autor, a alusão à chamada "herança clássica", revisitada por muitos intelectuais contemporâneos, está comprometida com a fundamentação de projetos de poder ou ideologias político-culturais. Nesse sentido, o passado é domesticado/instrumentalizado para atender a interesses e objetivos do presente. Assim, estudar o processo de aceitação e oficialização do Cristianismo, nos compêndios de História, oferece-nos a oportunidade de entender sobre a política imperial brasileira. A nosso ver, essa instrumentalização da História Antiga, nos manuais de ensino de História oitocentistas, sustenta a ideia de Nação pretendida pelos grupos elitistas que ocupavam espaços de poder no Império do Brasil.

\section{Produção, distribuição e utilização dos compêndios de História Universal no Brasil Oitocentista}

Por iniciativa de parlamentares ligados aos grupos políticos conservadores, tais como: Luiz Pedreira do Couto Ferraz (1818-1886) e Justiniano José da Rocha (1812-1862)², a década de 1850 foi marcada por muitas realizações no campo das instituições escolares. Por meio do Decreto 1.331A (BRASIL, 1854), foi aprovado o Regulamento da Instrução Primária e Secundária do Município da Corte, que determinava a criação da Inspetoria Geral da Instrução Primária e Secundária do Município da Corte - IGIPSC e, por extensão, do cargo de Inspetor Geral da Instrução, ligado ao Ministério dos Negócios do Império, cuja responsabilidade era fiscalizar e orientar o ensino público e particular nos níveis primário e secundário, estabelecer normas para o exercício da liberdade de ensino, reformular os estudos no Colégio Pedro II e os Exames Gerais de Preparatórios. Nesse sentido, confirma o excerto:

O Regulamento de 17.02.1854 criou, finalmente um organismo técnico-administrativo destinado a supervisionar o ensino primário e secundário, público e particular no município da Corte: um Inspetor Geral com atribuições claras e definidas, nomeado por decreto

\footnotetext{
2 Segundo Bastos (2008)Justiniano José da Rocha estudou na França, no Liceu Henry IV, e tornou-se professor de Geografia, História Antiga e Romana no Colégio Pedro II. A trajetória do professor oferece indícios sobre as razões pelas quais os compêndios franceses eram os preferidos nas escolas secundárias.
} 
Imperial; um Conselho Diretor constituído sob a presidência do Inspetor Geral e composto do reitor do Colégio Pedro II, de dois professores públicos e um particular e de mais dois membros nomeados anualmente pelo governo; delegados de distrito encarregados de auxiliar o Inspetor Geral na visita e inspeção dos estabelecimentos públicos e particulares de instrução primária e secundária (HAIDAR, 1972, p. 114, grifo nosso).

Aprofundam-se, dessa forma, os mecanismos de controle e vigilância da instrução pública, uma vez que caberá, especialmente ao Conselho Diretor, a tarefa de examinar e comparar métodos e sistemas de ensino; construir uma lista de compêndios aprovados para uso nas escolas; emitir parecer quanto a infrações disciplinares dos professores bem como estabelecer condições rigorosas para o exercício do magistério público e particular que passam a ser condicionados a exames públicos, destinados à apresentação de provas de moralidade e capacidade.

Turin (2015) adverte-nos para o fato de que, a despeito dos exames de contratação de professores, o modelo de ingresso desses docentes era basicamente por indicação. Assim, cabia ao estado, na figura do Inspetor Geral, as nomeações e exonerações. Além disso, tais docentes, em geral, exerciam mais de uma função pública.

É importante destacar que, a partir de 1854 , os exames preparatórios para acesso ao ensino superior passaram também a ser elaborados de acordo com os programas de ensino do Imperial Colégio Pedro II - ICPII. Assim, logo as instituições de instrução secundária provinciais buscavam adequar-se aos programas elaborados por ele. Convém esclarecer que, tal como previa a Reforma Educacional de 1841, a instrução pública secundária passou a ser distribuída em sete séries que, após a Reforma de 1854, subdividiu-se em dois cursos distintos: estudos de $1^{\text {a }}$ classe, realizados em cinco anos, em que se conferia um certificado especial que habilitava os estudantes a profissões liberais; e de $2^{\text {a }}$ Classe, que compreendiam estudos avançados de Latim, Grego, Alemão, Italiano, Geografia e História Antiga, Geografia e Idade Média, Filosofia Racional e Moral, Retórica e Poética.

Nota-se que os conteúdos de História que permaneceram, nos anos finais, de acordo com o Programa de Ensino para o ano de 1856 dirigiam-se aos estudos clássicos e medievais (Vechia e Lorens, 1998). A Reforma pretendia satisfazer às novas demandas que emergiam de uma sociedade que ambicionava o progresso material, a exemplo dos estados-nacionais europeus. A primeira etapa escolar reunia conhecimentos propedêuticos às carreiras comerciais e industriais. As séries posteriores dedicavam-se ao aprimoramento da formação clássica. É importante destacar que essas reformas educacionais foram influenciadas pelos sistemas de ensino secundário francês (Ensino Secundário Especial) e alemão (Realschulen) que almejavam propiciar melhor preparo básico àqueles que buscavam profissões técnicas, o que sinaliza as conexões de intelectuais e parlamentares brasileiros com projetos educacionais europeus. Tal iniciativa fracassou, visto que, em um país escravocrata, as profissões técnicas e manuais eram associadas aos escravos ou artesãos livres.

A formação humanística, por outro lado, tornar-se-ia o elemento de distinção social que habilitaria os estudantes secundaristas ao ingresso no ensino superior e em cargos públicos civis e militares. Queremos dizer, com isso, que a polarização de estudos científicos e literários se tornou objeto de crítica e as demais reformas educacionais mantiveram o caráter ambíguo da instrução secundária. De um lado, formar para as carreiras comerciais, industriais e agrícolas e, de outro, para as carreiras públicas civis e militares ao longo de sete anos.

No que tange à distribuição e utilização dos Compêndios, o Art. 106 do Regulamento diz que "os professores e directores de estabelecimentos particulares poderão adoptar quaesquer compendios e methodos que não forem expressamente prohibidos" (BRASIL, 1854, online). 
Nesse sentido, é questionável o motivo pelo qual uma determinada obra pode ser aprovada para uso nas escolas secundárias e outras não. Em primeiro lugar, destacamos a posição social e lugar de fala dos autores dos livros escolares, que eram predominantemente professores públicos do ICPII, da Escola Militar ou da Escola da Marinha ou magistrados, a maioria ligada ao Instituto Histórico e Geográfico Brasileiro - IHGB. Além disso, muitos desses escritores tiveram formação no exterior, sobretudo na França; outros foram egressos das Faculdades de Medicina, de Direito, das Escolas Militares ou das próprias escolas secundárias, além das Escolas Normais ou Seminários (BITTENCOURT, 2008).

Durante o Império brasileiro, os professores-autores derivavam de grupos sociais comprometidos com o projeto de nação que se pretendia forjar, a saber: grupos sacerdotais, militares, médicos, magistrados ou leigos que desfrutavam de "bom testemunho" junto aos pares. Gondra e Schueler (2008) ressaltam que ser professor no Império brasileiro requeria não só o pertencimento a categorias sociais que ocupavam espaços de poder e experiência profissional, mas também a averiguação da moralidade. No âmbito da moralidade, afirmam que:

relacionava-se à totalidade dos aspectos de sua personalidade, incluindo a sua conduta moral, familiar e sexual, os seus hábitos de vestir e falar, os seus gestos, os seus comportamentos na vida pública, as suas formas de ensinar e de administrar a escola, os espaços e os tempos escolares e os exemplos que sua figura espelhava - para além da sua apresentação e da sua inserção na vida social da comunidade, do atendimento aos requisitos exigidos para o exercício da docência e da obediência às normas e aos regulamentos estatais. (GONDRA; SCHUELER, 2008, p. 177)

Entendemos que a moralidade também pode ser interpretada como a capacidade do candidato à docência em se articular com uma gama de interesses políticos locais, do Estado, da Igreja, dos pais e das famílias com quem dialogavam por meio da instrução dos jovens.

De maneira geral, os compêndios eram traduções de livros didáticos franceses ou resultado da compilação das anotações de aula dos professores a partir das lições dos manuais também franceses. Manuel Duarte Moreira de Azevedo, professor de História Antiga e Moderna do ICPII, membro do IHGB e autor do Compendio de História Antiga, na seção Ideias Preliminares, que antecede os capítulos de sua obra afirma que:

Tendo de lecionar a história antiga aos alumnos do $2^{\circ}$ anno e do $3^{\circ}$ do Imperial Collegio de Pedro II, reconhecemos que os compendios existentes, escriptos na nossa língua, não convinhão ao ensino, não só pelo estylo, aliás correcto, porém difficil á comprehensão dos meninos senão pelas considerações e apreciações philosophicas que não podião ser comprehendidos por alumnos de menor idade, e cuja intelligencia ainda não se acha desenvolvida. Não havendo um livro, que podesse ser adoptado, seguimos o sistema de postillas dictados aos discípulos. Reunindo hoje em compendio essas apostillas, dandolhes melhor fórma e maior desenvolvimento procuramos não esquecer que escrevíamos para alunos que começão o estudo da história (AZEVEDO, 1864, p. s/p, grifo nosso)

Nota-se que o autor critica os compêndios anteriores e justifica, no prólogo de sua obra, a relevância de seu compêndio. Ao fazer isso, destaca os mecanismos de produção de tais livros 
escolares, que consideravam as particularidades do público a que se dirigiam: alunos do $2^{\circ}$ e $3^{\circ}$ anos do ICPII. Em segundo lugar, a obrigatoriedade do ensino religioso nos programas curriculares e o papel da Igreja Católica junto ao Estado evidenciam a relevância da confissão religiosa desses autores de livros escolares, de tal forma que a compatibilidade dos conteúdos veiculados à moral cristã poderia ser decisiva para aprovação ou não dos compêndios. A adequação da linguagem ao público-alvo também era objeto de atenção. Quanto mais apropriada aos jovens, mais fácil seria a memorização dos conteúdos. A aprendizagem resultava na capacidade de retenção, pela memória, dos conhecimentos escolares.

De acordo com o Regulamento (BRASIL, 1854), em seu Art. 115, seria aplicada uma multa de 15 mil reis "quando os professores usarem livros e exemplares para o ensino não autorizados competentemente". Com tais medidas coercitivas, associamos a instrução pública secundária a uma agenda de ação política comprometida, não só com a centralização da unidade político-administrativa, mas também "com a formação de um ethos comum, voltado a um estrato social específico, destinado a ocupar [...] cargos administrativos estatais" (TURIN, 2015, p.303).

Partia-se do pressuposto de que os livros escolares e o professor eram portadores de um conhecimento verdadeiro que deveria ser retido e reproduzido de memória. Tendo em vista os esforços pela implantação de propostas educacionais padronizadas à Nação, o uso de livros escolares, chancelados pelo Ministro do Império, tornava-se condição sine qua non [sem a qual não] à pretendida homogeneização da instrução pública que se direcionava, por sua vez, à formação de uma categoria social dirigente que passaria a se identificar (e se diferenciar) pelo uso de certos códigos culturais, no interior dos quais salientamos os estudos clássicos.

O Regulamento da Instrução Provincial de São Paulo/1869 (apud BITTENCOURT, 2008, p.58) ordenava o seguinte: "Art. 95 - O Governo garante premios na conformidade da $2^{\text {a }}$ parte do Art. 56 aos que compuzerem ou traduzirem compendios, os quaes serão sujeitos á disposição do $\S 4^{\circ}$ do Art. $3^{\circ}$ combinada com a do Art. $4^{\circ}$ ". Logo, em virtude da necessidade de livros escolares em português, a escrita dos compêndios era uma atividade fomentada pelo Estado para atender às demandas, sobretudo da instrução secundária. Tratava-se de uma atividade remunerada e digna de reconhecimento institucional, elaborada por homens comprometidos, ao que se espera, com a Nação e com a moral de sua época. Portanto, tal tarefa era revestida de um tom patriótico, honroso, digno de homens públicos. Pelas obras chanceladas pelo Império, nota-se que escritores quaisquer não eram aceitos para tais produções, afinal, era necessário domínio de línguas, estrangeira e nacional, bem como o conhecimento dos conteúdos publicados nos Programas de Ensino e certa influência política junto a Inspetoria Geral e junto a editores.

Na medida em que o Estado fomentava a escrita de livros didáticos, também restringia ações pedagógicas diferenciadas dos professores que poderiam tratar de assuntos subversivos à ordem política vigente ou contrários aos objetivos educacionais pretendidos. Segundo Bittencourt (2008, p.54), legisladores como Gonçalves Dias e autoridades religiosas, em discursos proferidos na Assembleia, partiam do pressuposto de que o emprego dos compêndios era essencial para uniformização do conteúdo educativo para o conjunto do País.

De 1808 a 1822, a publicação dos livros estava sob a responsabilidade da Impressão Régia. A partir de 1822, as publicações tornaram-se responsabilidade de iniciativas privadas, sendo que até meados da década de 1860 , as três editoras que mais se destacaram na produção de textos didáticos foram: B. L. Garnier (origem francesa), E \& H. Laemmert (origem francesa) e Francisco Alves \& Cia (origem portuguesa), que somavam 44,2\% de toda produção nacional. Tais editoras localizavam-se no Rio de Janeiro. É preciso considerar que o estabelecimento de bons contatos entre o editor e representantes políticos ou membros do Conselho Diretor era indispensável para o nascimento e a sobrevivência das editoras no Brasil. Dissensões partidárias ou hostilidades entre o editor e a Inspetoria Geral poderiam 
interferir na apreciação dos compêndios. As grandes editoras buscavam o reconhecimento da Corte Imperial. Baptiste Louis Garnier, por exemplo, solicitou condecoração ao gabinete do Império por ter sido o editor que divulgou e fez circular a maioria das obras científicas e literárias para a instrução pública no País e foi agraciado com o título de "Oficial da Ordem Imperial da Rosa" (BITTENCOURT, 2008, p. 73).

A partir da reforma de Couto Ferraz, as editoras aumentaram significativamente as demandas de obras escolares e literárias. As tiragens variavam muito, mas raramente excediam a quatro mil exemplares anuais. De todo modo, a circulação de livros escolares superava os demais gêneros discursivos e sinaliza uma sociedade que se iniciava no mundo da leitura (BITTENCOURT, 2008).

As editoras provinciais, sobretudo em São Paulo (5), Bahia (4), Rio Grande do Sul (12), Maranhão (3), Pará e Amazonas (8) estabeleciam acordos comerciais com livrarias dos principais centros urbanos do País. No entanto, não se limitavam a isso. Após a aprovação de um compêndio junto ao Ministro do Império e a compra dos direitos autorais junto aos autores dos livros escolares, os editores seguiam à divulgação da obra.

Assim, as editoras investiam na divulgação das obras em panfletos publicados em jornais, almanaques e na própria capa dos compêndios com anúncios de materiais escolares e outros compêndios vendidos na livraria. Outra prática, segundo os estudos historiográficos, consistia no envio de exemplares aos diretores de escola para divulgação entre os docentes. Defendemos, dado o exposto, que os esforços pela centralização do sistema de instrução pública no Brasil oitocentista caminham pari passu [simultaneamente] ao processo de centralização política, sobretudo a partir de 1850. A gradativa vitória parlamentar de grupos conservadores, chamados saquaremas ${ }^{3}$, desde o início do $2^{\circ}$ Reinado, no interior dos quais identificamos Couto Ferraz, na pasta dos ministérios ${ }^{4}$, sinalizam a relevância de propostas educacionais afinadas à manutenção da unidade política imperial. Esses grupos apresentavam-se como defensores da monarquia, da escravidão e do café. Logo, eram apoiados por grandes proprietários escravistas, portanto agiam em defesa de interesses econômicos e sociais comuns.

Outro aspecto que não pode ser negligenciado é o fato de que o Império do Brasil era um Estado Confessional, o que requeria a união entre os poderes secular e espiritual. Por conseguinte, a construção de uma identidade nacional, bem como a legitimação do Estado brasileiro, não era concebida, neste período, sem a relação com a Igreja Católica. Assim, como o governo combateu, entre as décadas de 1840 e 1860, propostas de descentralização política, fomentada pelos chamados liberais, e movimentos contestatórios à ordem social vigente, apoiados, em parte, por membros da Igreja, houve esforços para dirimir a presença de clérigos politizados ou partidarizados que questionavam os empreendimentos políticos dos grupos saquaremas. Isso justifica a inclinação do governo em nomear bispos de tendência ultramontana ${ }^{5}$, não afeitos à política partidária e defensores da disciplina e da ordem instituída

\footnotetext{
3 "Saquarema" é a denominação dada por Lynch aos conservadores do Império. Saquarema é o nome do município do Rio de Janeiro onde um dos principais líderes conservadores, o Visconde de Itaboraí, tinha uma fazenda, onde o grupo se reunia com frequência. Os saquaremas defendiam a centralização do poder. De acordo com eles, o Brasil era um país enorme, mas sem infraestrutura básica e com povoamento inorgânico e população profundamente decaída. Cf. LYNCH, Christian Edward Cyril. "Saquaremas e Luzias: a sociologia do desgosto com o Brasil”. Insight Inteligência (Rio de Janeiro), v. 55, p. 21-37, 2011. De maneira mais específica, o termo "saquaremas" sinaliza a integração e subordinação dos conservadores provinciais ao projeto político dos conservadores do Rio de Janeiro, numa espécie de pacto das elites.

4 A Câmara dos deputados, neste momento histórico, era constituída apenas por um liberal entre 110 conservadores. Cf. CARVAlHO, J. M. de. A construção da ordem: teatro de sombras. 4. ed. Rio de Janeiro: Civilização Brasileira, 2003, p.256.

${ }^{5}$ Obeid reforça a tese de que os clérigos ultramontanos são assim denominados porque seguem as orientações de Roma, isto é, "do outro lado da montanha", tal como pressupõe a encíclica Quanta Cura e o Sílabo dos Erros. Cf. OBEID, R.I. Os debates em torno do estado confessional brasileiro do século XIX (1842-1889). Dissertação (Mestrado em Direito). Universidade de São Paulo, Faculdade de Direito, 2013, p. 65.
} 
no País, o que de fato se refletiu na diminuição dos clérigos no parlamento e em movimentos sociais. Segundo Santirocchi (2011, p. 190):

A queda na participação política do clero e seu desaparecimento dos movimentos revolucionários a partir de 1842 refletem o interesse manifesto do Estado em favorecer um clero disciplinado e apolítico, em vista da paz pública. Soma-se ainda a reforma eclesiástica colocada em prática pelos bispos de tendência ultramontana que passaram a assumir as dioceses brasileiras a partir de 1844 .

Santirocchi (2011) esclarece ainda que, com o apoio dos saquaremas, o governo passa a adotar medidas que minimizam a atuação político-partidária do clero, uma vez que padres e bispos tornaram-se figuras de autoridade junto às comunidades locais e, por conseguinte, detinham um papel importante na manipulação da opinião pública. Para a maioria dos conservadores, intervir na disciplina e na moralização dos clérigos, por meio do apoio aos ultramontanos, produziria impactos significativos sobre a moralidade e disciplina da população. O discurso do deputado Nicolau Rodrigues dos Santos França e Leite (18031867), à Câmara, no contexto de criação de um bispado no Rio Grande do Sul, é bastante emblemático nesse sentido:

Sr. Presidente, todo o governo que compreende a sua missão deve estar inteiramente convencido de que a religião é um dos mais sublimes meios de governar, que ela forma o homem no seu interior, o habilita interiormente para a união social: as leis civis unem os homens pela superfície, mas a religião os une pelo coração. Sendo assim, é inegável que nós devemos lançar mão de todos os meios para tirar deste sublime, deste majestoso princípio todas as vantagens que a sociedade tem direito de esperar. (ARAUJO, 1845, p. 94)

O excerto explicita a predisposição de parlamentares em apoiar os clérigos ultramontanos com finalidade de fortalecer o poder central, estabilizar o Estado e a ordem social.

\section{Concepções de História e a escrita da História escolar nos compêndios de História Universal de Victor Duruy (1865) e Pedro Parley (1869)}

Interessa-nos aqui salientar, para além da preocupação com o controle e a formulação de programas de ensino, o fomento à educação religiosa de cunho cristão, uma vez que as reformas educacionais de 1856, 1858, 1862 e 1877, portanto posteriores a de Couto Ferraz (1854), reservaram cadeiras específicas ao ensino religioso, tais como História Sagrada e Doutrina Cristã, Instrução Religiosa ou Ensino de Religião ${ }^{6}$, as quais eram alocadas no primeiro ano do secundário. Nas demais etapas escolares, consolidou-se a proposta de ensino de História Francesa, que se tornou comum no Brasil a partir dos manuais de ensino de Victor Duruy (1865). O estudo da História Sagrada segue-se ao estudo da História Profana, dividida em Idade Antiga, Média e História dos Tempos Modernos e, após a incursão pela chamada História Universal, migrava-se ao estudo da História Pátria. Identificamos aqui um duplo objetivo no âmbito do ensino de História: assegurar a manutenção da moralidade cristã como retificadora da ordem social e política, bem como ajustar educandos aos projetos políticos idealizados pela Monarquia. Nos

\footnotetext{
${ }^{6}$ Os decretos educacionais que introduziram o ensino de História Sagrada e Doutrina Cristã nas escolas datam de 17 de fevereiro de. 1855 e o artigo $5^{\circ}$ de 1857 para o Colégio Pedro II. Cf. BITTENCOURT, C. Livro didático e saber escolar (1810-1910). Belo Horizonte: Autêntica, 2008, p.102.
} 
manuais de Duruy, os estudos históricos não se restringem à genealogia das nações, mas principalmente ao progresso científico e material da humanidade (FURET,1986).

O Compêndio da História Universal, de Victor Duruy, foi traduzido pelo padre Francisco Bernardino de Souza em 1865. Segundo Bittencourt (2008), ao se comparar a versão original, intitulada Nouveau Manuel du Baccalauréat es Lettres, à versão em língua portuguesa, nota-se acréscimos e supressões do tradutor para ajustar a obra ao campo de experiências educacionais no Brasil e acentuar o tom cristocêntrico da escrita da História.

Duruy produziu o referido compêndio na década de 1820, na França, momento em que atuava como professor de História do Liceu Napoleão no contexto de restauração monárquica francesa e na reforma educacional de François Pierre-Guillaume Guizot, Ministro da Instrução Pública e líder conservador da Monarquia de Julho, instituída em 1833 (TURIN, 2015). Na França, Duruy, na condição de ministro, contribuiu para revitalizar o ensino de História, uma vez que a disciplina era considerada subversiva à ordem social de caráter monárquico reestabelecida. Duruy ocupou o referido ministério entre 1863 e 1869, momento em que suas obras foram traduzidas no Brasil.

Para o estudo da Antiguidade, a versão brasileira do Compêndio de História Universal, de Victor Duruy, apresenta a sequência dos Tempos primitivos até a queda do Império do Ocidente, organização e administração da Gália durante toda a duração do Império Romano. Quantitativamente, evidenciamos que os conteúdos de Roma Antiga referiam-se a aproximadamente $63 \%$ dos temas da Antiguidade presentes na seção História Antiga. Os temas da Roma republicana correspondiam a 20,32\% e da Roma imperial, 39\%. Tais indicadores denotam a opção do autor e, por extensão do tradutor, pelos estudos voltados ao Império e ao Cristianismo. Nota-se que a narrativa histórica escolar difundia uma conciliação entre o tempo laico e religioso. Tal abordagem resultou em formas de legitimação de sujeitos históricos que ocupavam espaços de poder, além de situar a Igreja como parceira inseparável do poder civil.

Sob esse aspecto, a Reforma Couto Ferraz (1854), inspirou-se nas discussões educacionais e da escrita da história escolar correntes na França. Além do estabelecimento de mecanismos de controle e vigilância sobre os compêndios escolares, tal Reforma foi influenciada pela lei Falloux (1850), em discussão na França, que pretendia conter o avanço de uma formação educacional laica - solicitada pelos republicanos franceses - na medida em que instigava o controle das congregações religiosas à administração de instituições escolares.

Nesse contexto, a escrita da História Antiga escolar, particularmente, a História Romana e suas literaturas conciliam-se ao Cristianismo, principalmente sob a pena de professores-autores brasileiros. Ou seja, ensinava-se uma "moral antiga" filtrada pela perspectiva judaico-cristã. Em outras palavras, o estudo não só das fontes latinas, mas também da Antiguidade converte-se num exercício para formar "bons" cristãos, e as narrativas escolares desqualificavam práticas não cristãs, tal como se nota no excerto:

A política de Roma era egoísta, o amor próprio a sua mola real. Os Romanos tinhão como os Gregos, Persas, Egypcios e outras nações antigas algumas noções de virtude e mostravão às vezes qualidades nobres e generosas. Mas faltava-lhes, como a todas essas nações, a verdadeira moralidade, aquella que Jesus Christo nos ensinou na simples máxima: "Faze aos outros o que desejas que eles te fação!" Como ellas, achava-se Roma privada daquela verdadeira religião, da qual aprendeu o gênero humano, o que todo poder fundado na injustiça há de ter mui curta duração. Por mais esplendido que o fosse o império romano, estava longe de possuir uma verdadeira gloria. Seu esplendor adquirido pelo roubo, seu grande renome podião 
ofuscar as vistas de um gentio; mas para um christão tinhão e têm pouco valor; ele considera essa magnificência como falsa e sem fundamento. (PARLEY, 1869, p. 240, grifo nosso)

Em relação às distinções entre a literatura pagã e cristã, Duruy afirmou que:

Havião apenas sofistas e rhetoricos como Libanio, poetas como Claudiano, fazedores de pequenos versos e epithalamios, literatura impotente e inútil; e a literatura e a arte, ainda estreitamente ligadas ao paganismo, cahião com esse culto, que apenas inspirava fé às populações rusticas do campo. A fé a vida, que retiravão-se do velho culto e da velha sociedade, passavão para um culto novo e para uma nova sociedade. $\mathrm{O}$ christianismo que se desenvolvêra e constituíra por através das perseguições, subíra emfim ao throno com Constantino e Theodósio (...) De seu seio sahia uma litteratura elevada, apaixonada, activa (Tertuliano, S. Ambrosio, S. Agostinho, S. Gregorio Nazianzeno, Lactancio, Salviano, etc.). (DURUY, 1865, p. 192, grifo nosso)

Parley $^{7}$ e Duruy, nesses excertos, demarcam a superioridade da cultura cristã por meio de uma cadeia de negações em que costumes, valores e princípios sociais não cristãos são concebidos de maneira dicotômica, ou seja, a partir de jogos binários (verdadeiro/falso; certo/errado; útil/inútil). Para a escrita da história escolar ${ }^{8}$, tal binarismo incorpora uma função instrutiva ou pedagógica na medida em que apresenta padrões de moralidade e excelência pelos quais ações humanas passam a ser julgadas; o que também implica, em contrapartida, o direito de ser julgado e de julgar-se pelos padrões que são relevantes sob a ótica do que é aceito, no interior das comunidades cristãs, como base para as relações interpessoais (BARTH, 1998).

Nesse sentido, os autores sinalizam, em suas narrativas escolares, as fronteiras culturais que distinguem um cristão de um não cristão por meio do reconhecimento, manutenção e validação das diferenças entre "nós" e o "outro", o que reforça o tom cristocêntrico da narrativa. Tais narrativas "legitimavam a monarquia, quer por sistema jurídico, quer pelo processo de sentimento religioso e de certa forma nacionalista, como pertencimento a um território e a uma fé" (MARTINS, 2008, p. 208).

Narita (2017) ressalta o papel elementar da religião nos processos educacionais brasileiros no século XIX. O compartilhamento de ações e valores contribui para inserir o indivíduo em uma comunidade a partir de processos de identificação social. Em outras palavras, a religião constrói e dissemina uma espécie de gramática social básica, voltada à moralização do pensar e do agir, por meio da qual os indivíduos se reconhecem. Sob essa ótica, percebe-se que, por meio da instrução pública, constrói-se um horizonte moral que integra a sociedade em torno de valores e princípios cristãos.

\footnotetext{
${ }^{7}$ Peter Parley foi o pseudônimo do escritor norte-americano Samuel Griswold Goodrich (1793-1860), que, a partir de 1827, começa a escrever diversos livros para jovens.Na versão brasileira do compêndio de História Universal, de Pedro Parley, os conteúdos históricos são organizados por continente e numa perspectiva temporal linear e causal. No Brasil, o Compêndio de História Universal resumida para uso das escolas comuns dos Estados Unidos da América do Norte de Pedro Parley foi traduzido pelo desembargador Lourenço José Ribeiro, , e aprovado para uso nas escolas secundárias pelo município da Corte em 1857, e, por muitos anos, foi utilizado pela Escola Americana de São Paulo. Todas as edições do compêndio de Parley estiveram sob a responsabilidade da Editora Eduardo \& Henrique Laemmert, situada no Rio de Janeiro.

${ }^{8}$ Convém salientar que muitos tradutores dos compêndios de História eram religiosos (fiéis católicos ou clérigos) Além disso, o Imperial Colégio Pedro II - ICPII, assim como outros liceus provinciais, contou com a presença de professores religiosos em número significativo.
} 
A sociedade civil oitocentista reconhece-se sob o prisma de um horizonte moral, indispensável, a nosso ver, à reprodução da vida social e à manutenção da ordem cívica do Império do Brasil. José Liberato Barroso (1830-1885), em sua obra intitulada A instrução pública no Brasil (1867), afirmou:

Os grandes princípios da moral christã podem, e devem ser ensinados nas escolas pela palavra e pelo exemplo. São as grandes verdades desse christianismo social, cujo trabalho invisível, no fundo das consciencias, e fora das confissões dogmáticas, é infinitamente mais geral, mais profundo, e mais poderoso, do que se percebe na superfície do circulo das Igrejas; desse christianismo, que penetra na legislação, costumes e idéas das sociedades modernas, que é alma da civilisação, uma corrente de idéas vivas, que purificou os elementos da ordem social (BARROSO apud NARITA, 2017, p. 141, grifo nosso)

O texto nos possibilita refletir sobre as relações entre religião, moral e instrução pública oitocentista. Nele, Barroso nos permite perceber que o Cristianismo, concebido no campo da moralidade, é entendido como condição sine qua non [sem a qual não] para a construção de uma sociedade nos moldes do projeto político monárquico brasileiro. Além disso, o magistrado destaca o papel formativo da religião, percepção que não circunscreve o ensino religioso apenas à defesa de uma instituição religiosa. A proposta de Barroso nos faz pensar a religião como um meio de orientação moral do agir socialmente, de tal maneira que a formação das condutas também implique a formação da consciência cívica. Abílio César Borges (1824-1891), conhecido como Barão de Macaúbas, em seu livro dedicado ao público infantil, Terceiro livro de leitura para uso da infância brasileira (1870), afirmou:

Sem religião não há moralidade. Toda a moralidade que não repousa sobre a base do amor de Deus e do respeito a sua lei, é perfeitamente van; um phantasma de moralidade, que o menor sopro dissipa. E eis o que explica tudo o que vemos. (BORGES apud NARITA, 2017, p. 166, grifo nosso)

Em seguida, argumentou:

Estudar a religião e a história não será para vós um mero acervo de factos e de datas; vereis nos grandes acontecimentos que ella narra, na conquista dos reinos, na ruina das dynastias e dos impérios, outras tantas scenas do drama providencial; outras tantas intervenções de Deus nos negócios d'este mundo (BORGES apud NARITA, 2017, p. 166, grifo nosso)

Sublinhamos o nexo entre história, religião e moralidade. Nessa relação, averiguamos a moralidade como derivação do religioso no campo da educação. Para Narita, a moralização do agir estimula a adoção de "condutas educadas", cuja ancoragem se encontra no espectro da gramática moral (paciência, perdão, caridade, civilidade, fidelidade, generosidade, trabalho, etc.), que tangencia a narrativa histórica escolar (NARITA, 2017, p. 171). Visto de maneira ampla, a constituição de uma espécie de gramática moral que permeia a escrita da história escolar oitocentista é objetivada no momento em que os professores-autores se reportam aos imperadores romanos simpáticos ou não aos movimentos cristãos durante do Império. 
A seguir, procedemos à exposição de excertos sobre os comentários de Duruy sobre imperadores romanos situados entre Constantino e Teodósio:

Tinha pois de novo o império um só senhor, mas o tímido e suspeitoso Constancio deixava-se governar pelas mulheres, eunucos e aduladores. Dado todo às questões religiosas, que o arianismo suscitava, sem que tivesse fé bem certa e bem viva, vio preparar-se no Oriente nova revolta. Queria Gallo o título de Agusto. Chamado à Ásia por meio de promessas lisonjeiras, foi conduzido a Pola, na Istria, e decapitado. (DURUY, 1865, p. 175)

Então, (Juliano), vendo-se sem competidor, abjurou o christianismo de onde lhe vem o apelido de apostata; professou publicamente o antigo culto e reabrio os templos, esperando poder conseguir que para eles voltasse o povo. (...) Severo para comsigo, affectava a simplicidade e até o cynismo de um rígido estoico, sendo também algumas vezes demasiado severo para comos outros. $O$ tribunal que creou em calcedônia para julgar os funcionários prevaricadores foi acusado de haver dado sentenças injustas (DURUY, 1865, p. 176)

No governo de interno era Valentiniano severo e às vezes cruel. Tinha só uma pena para todos os delitos: a morte. Mas em questões religiosas seguia a respeito de todas as religiões princípios de tolerância (DURUY, 1865, p. 177)

Os excertos denotam a preocupação de Duruy em associar a conduta moral dos imperadores ao compromisso com a religião, cujo modelo é Constantino e Teodósio, apresentados, no âmbito da narrativa, como protetores das comunidades cristãs e guardiães de valores e princípios cristãos. Os imperadores que não se ajustavam a esse modelo são mal avaliados, tais como Constâncio por sua adesão ao Arianismo, Juliano por sua aversão ao Cristianismo e Valentiniano por sua "natureza permissiva". O posicionamento dos imperadores diante da religião torna-se um parâmetro para compreender sua conduta moral e suas ações políticas. Isso posto, ao discorrer sobre os imperadores circunscritos entre Constantino e Teodósio, Duruy nos permite vislumbrar as condutas esperadas por um governante cristão em um evidente esforço para caracterizar as atitudes do que para ele não seria um bom governante. Notemos como tal narrativa apresenta sérias implicações ao cenário político do momento da escrita do referido Compêndio.

É importante salientar também que Duruy não explora, no corpo da narrativa, que, entre Constantino e Teodósio, o Império Romano volta a ser administrado por mais de um imperador. A rigor, há um imperador romano para o ocidente e outro para o oriente. ${ }^{9}$ Estrategicamente, Duruy não explica o arianismo, professado por Constâncio II, apenas o menciona brevemente para, em seguida, desqualificá-lo, sem que tivesse fé bem certa e bem viva. A vertente cristã nicena, aprovada pelo imperador Teodósio e professada pela Igreja Católica até hoje, é adotada como protótipo do Cristianismo, posicionamento que negligencia e obscurece as demais correntes cristãs que circulavam pelo Império Romano.

A nosso ver, a narrativa provoca nos leitores a percepção de que o passado é homogêneo, o discurso "vencedor", isto é, chancelado e autorizado pelas instâncias de poder. Buscava-se uma origem para o Cristianismo, por meio da qual se constrói uma cadeia causal

\footnotetext{
9 O credo ariano foi inicialmente defendido e divulgado pelo bispo Ário (280-335), que iniciou suas pregações como bispo de Alexandria em meados de 318.
} 
explicativa. Duruy seleciona aquilo que se encaixa no aparente desenvolvimento histórico linear que resultaria no campo de experiências no qual se está inserido e despreza ou silencia as demais experiências históricas. O passado é concebido a partir de um relato uníssono, causal, linear e teleológico, organizado para explicar o presente. Visto sob esse ângulo, o passado confere inteligibilidade à formação imperial e à própria constituição e gênese político-cultural do tempo presente, o que Hall (2002, p. 54) chama de mito fundacional e Martins (2008, p. 196). de agenciamento das origens.

Com base nos excertos registrados de Duruy, a nosso ver, na esfera educacional, os diálogos entre História e Religião revestem-se do papel de fiador das relações interpessoais, por meio do que Narita chama de rotinização de ações e valores (2017, p. $25 ; 133)$ que contribuem, por sua vez, para a integração do cidadão ao tecido social. A formação moral, que permeava os currículos da instrução pública secundária, externava regularidades e propostas coesivas entre os indivíduos, especialmente no tocante ao reconhecimento do bom governante.

A formação pretendida pelo Império do Brasil aos secundaristas, de um lado, focalizava a propagação de uma orientação moral, como princípio básico das redes de sociabilidade. De outro, a confluência de valores como diretriz à condução social dos indivíduos para assegurar o "bem viver no Império" (NARITA, 2017, p. 158). Greiner (2008, p.31) nos adverte para o fato de que a propagação de uma mensagem religiosa e as atividades de uma Igreja, nos currículos escolares, têm inevitavelmente repercussões políticas a partir do momento em que a difusão dessa mensagem não se circunscreve à esfera privada

Como se observa, no tocante à história escolar, a década de 1850 que se estende, a nosso ver, pelo menos até meados da década de $1870^{10}$, representa um território de diálogos e tensões entre a História Sagrada e a História Civil ou Profana. No âmbito do historicismo, porquanto a narrativa histórica torna-se um repositório de nomes, datas e acontecimentos, que se dirigem a um fim como se houvesse algo por trás dos fenômenos aparentes à percepção, ou seja, a suposta inteligibilidade da ordem dos acontecimentos passa a ser explicada por meio de uma espécie de fio condutor ou força motriz que encaminharia o devir histórico. Sob essa ótica, nenhum evento poderia ser compreendido se estivesse desconectado de uma totalidade, cujo princípio explicativo atrelava-se a uma linha temporal, marcada pela progressão dos fatos históricos na qual o Ocidente europeu simbolizava o paradigma civilizacional (WEHLING, 1992).

Tanto em Duruy quanto em Parley, nota-se, a adoção de uma concepção historicista da história, eivada pela noção de Providência Divina que pressupõe que a ordem dos acontecimentos seria arquitetada por Deus e a realidade histórica, por conseguinte, resultaria da ação e vontade divinas.

Dito de outro modo, evidenciamos, nos compêndios analisados, a utilização da versão providencialista do historicismo, tal como desenvolveremos a seguir. Para facilitar nossa exposição nos limites da escritura deste artigo, pautaremos a análise sobre o processo de aceitação e oficialização do Cristianismo nos governos de Constantino e Teodósio, respectivamente. Isso posto, no âmbito das dissensões políticas sob a administração de Constantino, Duruy inicia o $20^{\circ}$ Capítulo do Livro, intitulado Constantino - Triumpho do christianismo - Theodosio - Partilha definitiva do império romano - Queda do império do Occidente - Organisação e administração da Gallia durante toda a duração do império romano, da seguinte forma:

\footnotetext{
${ }^{10}$ Nossa proposição apoia-se na polarização entre história e religião, que se intensifica a partir da década de 1870 e resulta na Reforma de Leôncio de Carvalho (1878) em que Religião e História sagrada desaparecem, provisoriamente, e do ensino secundário oficial, a exemplo do processo de laicização dos liceus franceses neste momento histórico.
} 
Irritada Roma pelo abandono em que a deixavão os novos imperadores, deu a Maxencio, filho de Maximiniano, o título de Augusto (306). Tomou elle logo seu pai por collega, de modo que teve o império seis imperadores ao mesmo tempo: os dous Augustos, Gallerio e Severo, os dous Cesares, Constantino e Maximino, e dous usurpadores, Maxencio e Maximiniano. Severo foi vencido e morto por Maximiano [...] no ano seguinte morreu Gallerio, victima da vida desordenada que levava (Maio de 311). Succumbio também Maxencio aos golpes de seu cunhado Constantino que venceu-o junto à ponte Milvia, no Tibre. Foi durante essa expedição que excitou Constantino, no mais alto grao, em seu favor o enthusiasmo dos christãos, mandando colocar a cruz em seus estandartes. Víra ele, segundo refere Eusebio, bem que Lactancio nada diga a respeito, brilhar no céo uma cruz com estas palavras: "Vencerás por meio d'este signal" (312). Licinio sucessor de Gallerio, havia ao mesmo tempo vencido a Maximino, que envenenou-se (313). Tinha o imperio dous senhores apenas: Licinio no Oriente e Constantino no Occidente. Ainda era de mais [...] Querendo proteger os christãos, que seu collega perseguia, atacou-o Constantino [...] Despio-lhe Constantino a purpura, deixou-o viver; mas tempos depois mandou-o matar em Thessalonica (DURUY, 1865, p. 168-9, grifo nosso)

Duruy inicia o capítulo por meio de um juízo de valor atribuído à Roma, ou seja, aos territórios que estão sob a tutela político-administrativa e militar dos romanos no século IV d.C. Ao longo da leitura, fica evidente que a "irritação" de Roma está relacionada à presença de mais de um líder político no governo imperial, o que teria possibilitado a emergência de usurpadores como Maxêncio e Maximiniano que contestavam a divisão quadripartite do Império entre $o s$ dous Augustos, Gallerio e Severo, e os dous Cesares, Constantino e Maximiano.

No transcorrer da narrativa, Duruy informa, por meio do bispo Eusébio de Cesareia, que o Deus cristão concedeu apenas a Constantino sinais que o tornaria vitorioso, como se observa no excerto: Víra ele (Constantino), [...] brilhar no céo uma cruz com estas palavras: Vencerás por meio d'este signal. Em seguida, a sequência narrativa apresenta Constantino na condição de protetor da comunidade cristã contra infiéis, como Licínio, imperador romano do Ocidente. Constantino o teria derrotado e tornado-se senhor do Império Romano ocidental e oriental.

A trama construída pelo autor mostra em que medida a autoridade divina serviu de paradigma justificativo para a autoridade política do imperador Constantino, sobre eventuais rivais ou pretendentes ao exercício do poder. Deduz-se, a partir da trama, que a Monarquia é resultado da vontade e, por extensão, do consentimento de Deus a um só homem. Não é por acaso que o segundo tópico deste capítulo intitula-se Triumpho do Christianismo (DURUY, 1865, p. 169).

No que diz respeito à expedição a que Duruy se refere para demonstrar os esforços militares do imperador Constantino para conter as investidas do general Maxêncio (306-312), o qual foi derrotado na batalha da Ponte Mílvio (312), no rio Tibre, há indicações da operação historiográfica do referido professor-autor. Sabe-se que o episódio é narrado pelo bispo Eusébio de Cesareia ${ }^{11}$ (260/265-339) em História Eclesiástica ${ }^{12}$. No excerto supracitado,

${ }^{11}$ Eusébio de Cesareia nasceu em local desconhecido, mas se sabe que teve uma formação cristã na cidade de Cesareia, Província da Judeia. Foi ordenado bispo por volta de 313 e é provável que tenha morrido em torno de 340.

${ }^{12}$ Em História Eclesiástica, o bispo Eusébio objetivou discorrer sobre a trajetória do cristianismo, da origem à contemporaneidade, no interior da qual se verifica a preocupação em justificar o cristianismo como religião do "povo eleito", em detrimento de outros movimentos religiosos do império Romano. Defende a concepção de "monarquia cristã" e enaltece a autoridade imperial, tornando-o intermediário da vontade divina. Cf. 
nota-se que Duruy o menciona e acrescenta outro autor cristão: Lactâncio (240-320), o que demonstra a preocupação de Duruy em responsabilizar as fontes históricas pelas informações. Pedro Parley, ao contrário, assevera que:

Foi Constantino Magno o primeiro imperador que se fez christão. [...] Conta-se que Constantino indo um dia a cavalo à frente do seu exercito contra Maxencio, víra nos céos uma cruz e nella escriptas as palavras: "Com este estandarte serás vencedor". É esta visão, que se supõe ter convencido o imperador da verdade da religião christã e em virtude da qual ele se resolveu a adopta-la como religião de Estado. Daquelle período em diante a victoria do christianismo sobre a religião pagã estava certa. Desappareceu ante a cruz a mythologia da Grecia e de Roma, os ídolos do império do mundo cahirão quebrados pela força da verdade do Evangelho. Muitos templos dos gentios se convêrterão em igrejas e o povo, até então acostumado a curvar-se diante das estatuas de Jupiter e de outros deosos fantásticos, ajoelhou com humildade aos pés do signal da redempção. (PARLEY, 1869, p. 246)

Diferentemente de Duruy, Parley não se preocupa em citar fontes para subsidiar as informações históricas. No entanto, em ambas as narrativas, os autores nos fazem crer que, a partir de Constantino, o discurso cristão passa a ser autorizado, reconhecido e aceito pelas instituições políticas. A descrição desse cenário enunciativo também aponta para uma construção discursiva de caráter mais emocional do que analítico. Este aspecto reforça não só a concepção providencialista da História Universal, mas também a tentativa de conciliação entre a história sagrada e a história civil, proposta por Duruy (1865) e Parley (1869).

Outro elemento que nos chama a atenção, no tocante ao processo de escrita da narrativa histórica escolar, sob a perspectiva providencialista, versa sobre o uso de causas sobrenaturais para explicar a vitória miraculosa do cristianismo no IV século (CUCHET, 2012, p. 41). Os autores desconsideram as relações de poder entre bispos e imperador, bem como as circunstâncias históricas que possibilitaram a emergência e consolidação do discurso cristão, além de assumir o ponto de vista de autores tardo-antigos cristãos, como Eusébio de Cesareia e Lactâncio, na condição de verdade histórica.

A narrativa histórica não é construída a partir de um diálogo entre diferentes fontes históricas e vertentes historiográficas. Em vez disso, centram suas narrativas em um acontecimento imprevisto e miraculoso - Constantino [...] víra nos céos uma cruz e nella escriptas as palavras: "Com este estandarte serás vencedor" e partem de tal acontecimento para referendar o chamado triunfo do cristianismo (DURUY, 1865, p. 169; PARLEY, 1869, p. 255). Deduz-se, sob a ótica de Duruy e Parley, que a ordem dos acontecimentos não está dissociada da intervenção divina. Parley, por exemplo, admite que a Providência Divina está na engrenagem dos processos históricos $(1869$, p. 242), os quais não excluem feitos miraculosos e mudanças políticas arquitetadas pela própria divindade; em Duruy, isso fica subentendido.

Os autores pensavam a história a partir de pressupostos teológicos, a História, como resultado do triunfo progressivo de uma comunidade de fieis, despreocupada com questões políticas e devotada à propagação do Evangelho. No interior da narrativa, o acontecimento só se torna único e inteligível, quando relacionado a um "futuro teológico" (KOSELLECK, 2009, p.127).

Sob esse ponto de vista, entende-se que a vitória do Cristianismo decorre de uma espécie de acidente inesperado na história, que seria ininteligível se não se considerasse a 
intervenção direta de Deus. Nesse contexto enunciativo, a intervenção divina far-nos-ia compreender mais que o sentido por trás da ordem dos acontecimentos - o que equivaleria à crença na ordem providencial - mas principalmente o princípio ativo que impulsiona direta ou miraculosamente os processos históricos - o que alude à crença na ordem sobrenatural.

A predileção da divindade cristã pela Monarquia sinalizaria o consentimento divino em relação a essa forma de governo e a suas instituições políticas, o que endossaria o fato de que Deus é um agente histórico e a cooperação entre Deus e imperador asseguraria a harmonia social do Império/Nação, perspectiva evidenciada no excerto a seguir:

Foi em sua expedição contra Maxencio que declarou-se altamente Constantino defensor da fé christã [...]. Favorecia de uma parte as conversões, dando todos os empregos aos christãos, e concedendo privilégios às cidades que deribassem os altares dos ídolos; do outro lado, procurou acabar com a idolatria, primeiro por meio de exhortações dirigidas aos povos em numerosos edictos, e mais tarde, quando em todos os lugares triumphava o christianismo (...) O concílio de Nicéa, que reunio em 325, redigio a carta fundamental do christianismo. Logo, que encerrou suas sessões, escreveu o imperador a todas as Igrejas "de se conformarem com a vontade de Deos enunciada pelo concilio". Achavase terminada a revolução na ordem religiosa; o christianismo era agora a religião dominante do império, facto imenso e cujas consequências ainda hoje durão. [...] (DURUY, 1865, p. 171-2).

Duruy considerava Constantino um defensor da fé christã, o que teria viabilizado, em todos os lugares, o triunfo do cristianismo. Esforça-se em demonstrar a integração entre política e religião no processo de fundamentação dos projetos políticos do monarca. Inferimos que para os leitores de tais manuais, a história ensinava, " a partir dos inúmeros acontecimentos do passado que transmite regras gerais do agir ou, em outras palavras, regras ou princípios tomados como válidos para toda mudança no tempo e para o agir humano que nela ocorre" (RÜSEN, 2010, p. 51). Não se trata de repetir o passado no presente, mas de perceber, por meio da abstração das experiências do passado, regras do agir que orientem ações no presente. Em outros termos, essa percepção sobre o passado dava sentido a uma história que tinha a pretensão de ser universal, já que, por meio de casos particulares ou episódicos, o leitor apreenderia regras gerais de "validade atemporal", úteis à vida prática atual (RÜSEN, 2010, p. 52).

Tais narrativas escolares sugerem que, ao olhar para o passado, sob a ótica da História Magistrae, é possível apreender experiências exemplares ou úteis ao presente, sem abandonar, no entanto, a percepção da singularidade dos processos históricos e a possibilidade da progressão dos acontecimentos. (KOSELLECK, 2009, p. 54). É necessário "ressemantizar", no caso em questão, a ideia de Historia Magistra Vitae, vinculada apenas a uma concepção de História em que o passado oferece exemplos ao presente.

\section{Considerações finais}

Concluímos que, sob as óticas de tais narrativas escolares, o passado não só instrui o presente, mas também nos oferece suas origens. Adicionado a isso, veicula a noção de devir histórico, a nosso ver, essencial para o entendimento da história universal nos compêndios escolares do momento histórico em questão.

Nesse sentido, a narrativa histórica não apenas instruiria, mas também proferiria sentenças e juízos pertinentes ao presente e ao futuro. É, com o olhar voltado ao passado, que se buscava adquirir ensinamentos não só para o próprio tempo, mas também para o futuro 
(KOSELLECK, 2009, p. 60). De maneira mais ampla, situava-se o presente imperial em um continuum do cânone bíblico e de seus modelos de virtude.

Tal reflexão nos leva a concluir que os compêndios de História Universal, traduzidos para as escolas secundárias brasileiras, responsabilizavam-se por domesticar fragmentos do passado, na medida em que imprimia neles um sentido histórico que atendia a interesses e objetivos do presente e por ensinar aos leitores alcançaria os mesmos progressos materiais e científicos que a Europa civilizada desfrutava. Para Gonçalves (2009, p. 134), "o conhecimento histórico seria capaz de fornecer a orientação para materializar o tão almejado desenvolvimento civilizatório". Assim a fidelidade a um passado coletivo permitia pensar a identidade nacional a partir de visões de mundo e expectativas sobre a vida nos moldes dos estados-nacionais europeus, particularmente a França.

Insere-se, dito de outra forma, o império em um conjunto de experiências históricas que se ajustam a uma totalidade (história universal), cujo papel consiste em evidenciar a glória da civilização. Assim, a ideia de justificar a presença da História Universal nas propostas curriculares da escola secundária consistia na inscrição do Brasil na epopeia da civilização, o que incluía, pelo menos no âmbito literário, o país recém-independente na esteira de desenvolvimento dos países da Europa ocidental.

Entende-se, sob essa ótica, que a História Universal não é uma evidência, mas uma representação singular do passado. Tratava-se, especificamente, de uma representação particular do mundo, que, como sabemos, está ancorada no ambiente cultural e nos desdobramentos históricos das nações europeias (INGLEBERT, 2014, p. 7-8). No momento em que as narrativas escolares oitocentistas, tais como abordamos, veiculam e ativam determinados signos culturais (moral cristã), apresentam parâmetros para a ação e a interação político-social e utilizam o passado como reduto de acontecimentos fundadores para explicar o presente, influenciam e significam, pelo discurso, "tanto nossas ações, quanto a concepção que temos de nós mesmos" (HALL, 2002, p. 50), além de estabelecer mecanismos de distinção social (BARTH, 1998, 165).

Em um país, onde o catolicismo era a religião oficial, declarar-se cristão significava compartilhar uma tradição espiritual com a qual a nação se identificava. No século XIX, a concepção de nação e seus mecanismos de diferenciação são pensados, por muitos intelectuais - como já dissemos -, sob a ótica da fórmula: uma língua, uma cultura e um território. Nesse sentido, a nação se confunde frequentemente com um padrão de moralidade, como é caso do Brasil oitocentista, e a narrativa histórica escolar considera o cristianismo um legado ou herança que serve ao presente.

Nesse sentido, o fortalecimento do processo de escolarização e o fomento à produção de materiais didáticos a partir de 1850, em particular no âmbito do ensino de História voltado às escolas secundárias, cumprem o papel de disseminar um ideal de nação e de cidadão, na medida em que fomenta, por meio da escrita histórica escolar, um conjunto de formas de agir e pensar que estimula a cooperação dos indivíduos e a sensação de pertencimento a uma comunidade política específica, inspirada na ideia de nação europeia. Assim, a autoridade do passado, mais precisamente de conteúdos de História Antiga em manuais de História Universal oitocentistas, responsabilizava pela validação de experiências político-culturais úteis à fundamentação de uma ordem social e à integração do império do Brasil aos padrões de civilização cristã europeia.

\section{Referências}

ARAÚJO, M.M.R.. Carta Pastoral contendo as providências acerca do estado da Igreja do Rio Grande do Sul depois da pacificação da província. Rio de Janeiro: Tip. Americana, 1845.

AZEVEDO, M. de. Compêndio de História Antiga. Rio de Janeiro: Livraria Garnier, 1864. 
BARTH. F. Os grupos étnicos e suas fronteiras. In: POUTIGNAT, P. \& STREIFF-FENART, J. (Org.). Teorias da etnicidade. SP: Editora Unesp, 1998.

BASTOS, M.H.C.. Manuais escolares franceses no Imperial Colégio de Pedro II (1856-1892). História da Educação (UFPel), v. 12, p. 39-58, 2008.

BITTENCOURT, C. Livro didático e saber escolar (1810-1910). Belo Horizonte: Autêntica, 2008.

BRASIL. Decreto $\mathbf{N}^{\mathbf{0}}$ 1.331-a, de 17 de fevereiro de 1854: Approva o Regulamento para a reforma do ensino primario e secundario do Municipio da Côrte. Rio de Janeiro, RJ, Disponível em: https://www2.camara.leg.br/legin/fed/decret/1824-1899/decreto-1331-a-17fevereiro-1854-590146-publicacaooriginal-115292-pe.html. Acesso em: 18 abr. 2019.

CARVAlHO, J.M. A construção da ordem: teatro de sombras. 4. ed. Rio de Janeiro: Civilização Brasileira, 2003.

CELlard, A. A análise documental. In: POUPART, J. et al. A Pesquisa Qualitativa: enfoques epistemológicos e metodológicos. Petrópolis, RJ: Vozes, 2014, p. 295-316.

CUCHET, G. Comment dieu est-il acteur de l'histoire? Revue des sciences philosophiques et théologiques, n.01, 2012. https://doi.org/10.3917/rspt.961.0033

DURUY, V. Compêndio da História Universal. Trad. Francisco Bernardino de Souza. Rio de Janeiro. Ed. B. L. Garnier. 1865.

FURET, F. A oficina da História. Trad. Adriano D. Rodrigues. Lisboa: Gradiva, 1986.

GONÇALVES, S. C. Pensamento civilizador e escrita da história: origens da historiografia do Instituto Histórico e Geográfico Brasileiro. Dissertação (Mestrado em História). Faculdade de História, Direito e Serviço Social, UNESP/Franca, 2009

GONDRA, J.G; SCHUELER, A. Educação, poder e sociedade no Império brasileiro. São Paulo: Cortez, 2008.

GREINER, P. Genèse de la laïcité et prohibition du prosélytisme. Tranversalitès, v. 4, $\mathrm{n}^{\circ} 108$, 2008. https://doi.org/10.3917/trans.108.0021

HAIDAR, M.L.M. O ensino secundário no Império brasileiro. São Paulo: Grijalbo, Editora da Universidade de São Paulo, 1972.

HALL, S. A identidade cultural na pós-modernidade. Tradução: Tomaz Tadeu da Silva \& Guaciara Lopes Louro. RJ: Lamparina, 2012.

INGLEBERT, H. Le monde, l'histoire: essai sur les histoires universelles. Presses Universitaires de France: Paris, 2014. https://doi.org/10.3917/puf.ingl.2014.01

KOSELLECK, R. Futuro passado. Contribuição à semântica dos tempos históricos. Rio de Janeiro: Contraponto; Editora PUC/RJ, 2006, p. 41-60. 
LYNCH, C.E.C. Saquaremas e Luzias: a sociologia do desgosto com o Brasil. Insight Inteligência (Rio de Janeiro), v. 55, p. 21-37, 2011.

MARTINS, A.L. Pensar as origens. História: Questões \& Debates, n.48/49, p. 195-223, 2008. https://doi.org/10.5380/his.v48i0.15301

MEDEIROS, E.B. Ser cristão no século IV: identidade em História Eclesiástica de Eusébio de Cesareia. Dissertação (Mestrado em História) - Programa de Pós-Graduação em História. Instituto de Ciências Humanas. Universidade Federal de Pelotas, 2012.

NARITA, F. Z. A educação da sociedade imperial: moral, religião e forma social na modernidade oitocentista. Curitiba: Editora Prismas, 2017.

PARLEY, P. História Universal resumida para uso das escolas dos Estados Unidos da América do Norte. Trad. Lourenço José Ribeiro. Rio de Janeiro: Eduardo \& Henrique Larmmert, 1869.

OBEID, R.I. Os debates em torno do estado confessional brasileiro do século XIX (1842-1889). Dissertação (Mestrado em Direito). Universidade de São Paulo, Faculdade de Direito, 2013.

RÜSEN, J. Tópica: formas da historiografia. In: História Viva. Teoria da História III: formas e funções do conhecimento histórico. Trad. Estevão de Rezende Martins. Brasília: Editora UNB, 2001, p. 17-84.

SANTIROCCHI, Í.D. “Afastemos o Padre da Política! A despolitização do clero brasileiro durante o Segundo Império". Mneme (Caicó. Online). Natal: v.12, p.187 - 207, 2011.

SILVA, G.J. Os avanços da História Antiga no Brasil. In: XXVI SIMPÓSIO NACIONAL DE HISTÓRIA - ANPUH, 2011, São Paulo. Anais... . São Paulo: s/e, 2011. p. 1-31. Disponível em: <http://www.snh2011.anpuh.org/resources/anais/14/1300246828_ARQUIVO_ OsavancosdaHistoriaAntiganoBrasil.pdf $>$. Acesso em: 15 abr. 2019.

TURIN, R. A prudência dos antigos: figurações e apropriações da tradição clássica no Brasil oitocentista: o caso do Colégio Imperial Pedro II. Anos 90, Porto Alegre, v.22, n.41, p. 299320, 2015. https://doi.org/10.22456/1983-201X.49864

VECHIA, A; LORENZ, K.M. Programa de ensino da escola secundária brasileira: 18501951. Curitiba: Ed. Do Autor, 1998.

WEHLING, A. Fundamentos e virtualidades da epistemologia da história: algumas questões. Estudos Históricos, v. 5, n. 10. 1992, p. 147-169. 